This work is licensed under a

Creative Commons Attribution-NonCommercialNoDerivs 3.0 Licence.

To view a copy of the licence please see:

http://creativecommons.Org/licenses/by-nc-nd/3.0/ 
SOCIOPOLITICAL IMPERATIVES IN THE HISTORY OF HEAITH DEVELOPITNT IN KENYA

Bv

\section{F. H. Muru}

Working Paper No, 374

INSTITUTE FOR DEVELOPMENT STUDIES

UNIVERSITY OF NAIKOBI
P.O. BOX 30197

IIAIROBI, Kenya

November, 1980

Views expressed in this paper are those of the author. They should not be interpreted as reflecting the views of the Institute for Development Studies or of the University of Nairobi.

This paper has protection under the Copyright Act, Cap.130 of the Laws of Kenya. 
SOCIOPOLITICAL MMPEHAIIVES IN THE HISTORY

OR HEAITH DTVELOPAEETT IN KBNYA

\section{ABB̃ THACT}

European Colonial Powers have shaped the piilosophies and the social structures $i$ in their former colonies. Institutions currently dominating lives in the African states are a reflection of colonial domination. The thrust of colonial activity was to nold political systems, socioecononic activities and cultural patterns which were largely consistent with the prevailing or desired European molds. The greatest hindrances to change in the health and other systems in Africa today lie in what was inherited, however inappropriate. A historical analysis of the Kenyan health care system shows that inheritance from Britain has not veen lost, it is being strenginened. The prevailing health system is tailored to suit the croving and inevitable sociomecononic classes. 
Iij/ 374

SOCIOPOLITICAL MIPEIRATIVES IN THE HISTORY

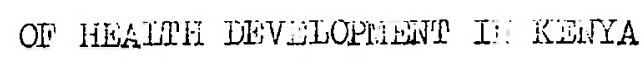

\section{ITHERODUCTIOIS}

The recent history of Alrica has been largely influenced by European colonial powers; colonial history has affected the social-econonic ins titutions, structures, social philosophies and the perceptions of African societies both from within and without. Kenya, like other iomer colonies, has not been irmune fron diverse forms of donination through concuest. And her institutions have been shaped accoraingly, sometines by way of protest and sonieticies by way of: positive responise to colonial penetration. The thrust of colonial donination wes to mold systems in the coloujes which ware appropriate to the socioecononic patterns arising out of the developient oituation in vinich the colonisin countries were. Indead socioeconoric anilysis of both colony and metropolis shows a developmental pattern underlying race rationships or political structure in the colonies. This paper focusses on one of the najor institutions - health - and shows the deteminants of inistory on the heulth systews we have today. Broadly, the development of human sucieties is affected by four closeIy intertwined areas or human activity! the politickl; the socioeconoric; the cultural and the wedical. In this paper 1 have taken malical to rafer to the ideaolosy governing the concepts of health and discase.

Froin these four ractors, the strongest and nost lar reaching is the political. Political activity deteranes the magnitude, and the direction of the rest. Socipolitical history cimonstrates that the principal deteminants of the velfare of the porulation ix: Kenya during colonial rule were the very thrust of colonial conquest. The yaper further sinow the influence of political economy on the health systern in Kenya,

\section{Areas ü Colosial Conquest}

In Kenya, colonization : tartcd about the end of the 19 th Century and quickly covered the Iour broady related arcas mentioned giove. The first of those areas, and as noted the nos ts lundanent:al, was the political sector. Indigenous ethic groups and their systems of Evverment were subjugated under a new, Iruposed systeri. Instead of paramount chieîs snc elders of the clans, complicated net-work of "inlers", starting with an inposed chief and culninating in District and froviaclal Corulissiunerrs, end a goverror it the aper, was instituted. The tribal council hat to give way to a cumcil of minifims, and later to a parliaventary system, from which the indiguns wejles were excluded. In this way there was total uxclusion of the African from the arema of aelf detemination n. Decisions were nade by others ax behalt of Africens. The dencil of political righis to the Alricen was the bexis for other aress of expopriation, for 
without politicel power thero was nothing the indigencus populations could do.

Sinilar kinas of suciopolitical systeri were to be found in nost forner Buropean colonies like llozankigue and $\mathrm{Ang}_{\mathrm{B}} \mathrm{la}$, in zaire, and in otier former British colonies like Zambia and Zimbabwe. Colonial dontination are invariably sinilar.

The second area of conquest was econouic. This conguest changed the existing liodes or production and distribution of buncits, and reversed the rationale for economic activity . Ordinarily, people spend themselves for their own welfare. Under colonial rule, howcver, the rationile of proâction, and the associated aconanic activities and result were por tile benefit of the citizens of the United Kirsom. Without exception, this rule splied in all colonized societies. The African populations wee used (and are still used, notably in South Africa) as a cheap neans of profit-making for tiripopean \& North American enterpreneurs. The labourers were not citizens, comperable to the European irunigrants. On the contrary, they were relegated to the lowest rank in a two or three-tier sociopolitical systeri. In Kenya, for instance at the top of the structure was the European race, below which wo the Asiatic race, and even further dow the African. As would be expccted, the pyranidal structure had a wide base to supjort but al shari epox of Buropean colonial officials, fariters, businessmen and a corps of professionils. Under coloniel rule the means of production and the result theroof vere ior the bentits of the citizens, of the United Kingduril. The colonized people vere not citizens, inspite of all the African peoples who died during the world wars, laving dow their lives for their inetropolitan nestors.

The third type of conquest was the cultural. Cultural conquest destroyed or attempted to destroy the African ways of living and belief systems, relioious, ious, social essimilation pattems and customs. Iros example the pulpit was used not always to spread words of Christian love and justice, but often, rather to

condemn sorne saciad and intergral African custoins. Notable anong these areas of antagonisin was the Agikuyu Penal circuncision anci related ceremonial activities. Kenyatta's Ialous defence of ferile cixcuricission in the early 1920 s became a rallying point in the strugigle for independence. In Uganda, for instance, the Bagancia expected a well-brought up rutvre bride to have manipulated and enlongated Labia ninora for the purpose of strustioning future marital sexual bonds. The custon was rot spered condemation by turopean reliorious leaders. It was argued that the custon was (or is) prinitive and inoral. Quite obviously, the understanding of tie custom by the Europeans was rare, if at all, perhaps there was no atteipi on the part of Ruropeens to understand such customs. Infact other custows and beliefs were not jimure fron attocts. "African fom of praver are even today, often regardod as the glorifiad work of evil snics.ts at best, or oî satan, at worst. 
The fourth area of colonisl dolination followed the patter-estailished by the other three, indeed thag had prepared the grunds, as it werc, in which this last would flourish. The obove thres set the tone $\vec{f}$ or the existing halth care systen for nedical conquest.

No society has existed without a relatively efective health care system that cen cope with social, psychological, econoric and physical ills or areas of dishamony. The traajitional African health systom is perhaps best known for the Haintenance of sone established balsuce between the indivioual or the community, on the one hand, and the exvironent surrounding people, on the other. In this equation is included the spiritual sopects. The practice or this traditional health systen is tuigue in meny respects, especially in the interactions between the patient and the cuctor wa the patient dnd the fanily. Whille the aoctor way be a recomized speciolist, the "feelinglessness" and detachnent characteristic of a nodern health care syster does not exist. In. most"cases, the doctor is lunown by either the patient or the members of his clan. Or necessity, with a fev excentions, the traditional doctor shares the belief system of the patient. Indeed, the doctor and the petient belong to the sane integrated sociocultural group supported oy cun established franework of. social nome. This last aspect probebly expleins the high rrescription cowpliance rate in traditionel health systeme.

The nedical care systow existing todsy was ontrenched in Africe partly as a direct attempt to supprass traditicnal Alrichn systers (including health) and partly, and more inportantly as a nocosiary condition for colonial "stevardun" ship of dependent peoples". Dvon today, nodern redicine, in conjuction with other nodern institutions, atteripts to show that ilost aspects of tracitional nedicine are detrinextal. When rodern ncaical syston waw established it was believed that a winimun standera of health of the "notives" was a necessary condition for the Airicen to be able to rrovide minimu vork performsnee in whatever assigrizents vere given hir. Turthersore, the healtin of the European settlers was indecd partly dependent on the health status of the natives. The

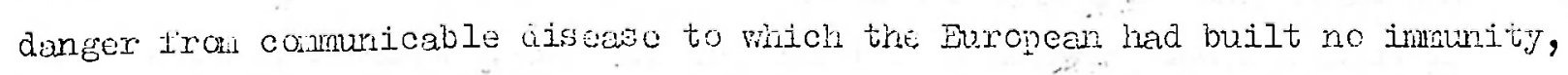
was always jescat. The use of malaria, cholore and bluckwater fever as a comon "dens ex-rachins" in nincteerth onä varly trchitieth century fiction, reflected a very real conctm and cecptonce in colonial cultur.. Eflective cintrol or such diseuse voula be linitud unless. the selves froe of such maladies. The Europen uployers were thereforc, adizised by the health department to invest in the heeltin of their native labourers, for in them lay the very survivel and success of the omplover. In 1927, for ande, the Director of hedical and Senitary Survicu Dr. Join Gilks (1) wrote in his annual roport:- 


$$
-4 \cdots
$$

"Enployurs of labour wal tomship or imuicipality authorities must realize that tho native living undur insanitary conditions is a canger to the jublic helth of the prim or tomsip and that proper provision just be nacie $I$ OI his accoinodation under sanitary conations 17 tho healih of the other cominitios is to renin satisfactory and uconouic progrusis is not to be rotarclu".

Gijks recounduation ran countiv to the very riviple of colonization: uxploitation of both the colonized and thir environient (2). The colonial of ice in London ond its local adrinistrative wing had so far fuund it hara to nodiry this principle. It was perhaps ior this reason tinat Gilks issuca a cauticus rocomendation regarding the health status of the Arrican lebourcre, nany of whoid had died in the First Forld war on the side of the allies. Inimuating that shortsightedness was endenic dur.ing government officialsari local entreprenours rogarding an effective and efficient labour iorce, Gilks (1) rrote:-

There is now, anong nany of the lore far-seting employers, a feeling that tiwe is ripe for nore definite requirements on the part of Goverm nent as to the conditions undar which labourers should live and be enployed, and altiost cnough naterial has bean collected to eneide such requirements to be formuted. This, of curse vill have to be done with caution! ! (mphosis adica).

Accordinfly the then health officials could not even recommend training of Africans. The time was not ripe (3).

Even progressiva nedical cxperts nero not out to upset the colonial apple cart! In short, the nudical syster, vigorously instituated, was designed to benefit the European iniligants. The Africans were just a necessary problen of that maintanance process. Total noglect of the natives was demed impossiblo in risw of the itportance of pative labour and $\therefore$... in view of high prexalence of infectous discasus. Medical experts therefore rocolliunded health pronotion for poprilations in both. native ruserve and settled areos. "No section can be nuglected tither in settled arca or in native ruserve without sone other section buing prejudicially affected."

Understanding of the arwas of colonialism outlined abovo and their efiect on the current saakel syatu is not only desirable but necessary. Medicine, sociaeconosic values, poljtical norms and indeed the whole society are closely intertwined. 
"The understanding of thi structutes, functions, and relues of scaial organisations is not optional or uloctive $P$ or meaicine and public health, but imperative. The scicnces of social men and of individual behaviour are an intergal part of basic nicdical sciunce." The peintenence of any particular systein requires partly on articulated regulatiory syst til, partly an established nomative systen aid partly instibutions stafied by individuals devoted toothe survival of the systen. It would have been cowplitely out of character to have a colonial syster mun by people who did not believ; in the systen.

Indeed, in Kenya and other African countries, we see a similar patturn of systen naintenance energing, perhaps nors forcefully. With a few exceptions, staffing of nany public institutions is often based on loyalty to the systeri rather than ability to run the systen. Tho hoelth ileld is not exception. The growth of hospitals is thus a losical developrent and will probably continue until health systu goals are changed and stafied ith personnel who believe in the change.

Sociohistorical Duvelopment and hudical Cire

Missionary groups established a toothold in Kenya about 1890. They were precedei by the Imperital British East African Compeny (I.B. P.A.) in 1888. In 1895 colonial dunination over Kenya mas purmerly vifected. In 1920, Kenya becane a British Colony and Prutectorate. This statis lasted until 1963 when Kenya attained j.ndepundence and the following yeare she becaue a republic vithin the Gomonealth. Since the establishrent of formal colonial adrinistration the three establisments - I.E.E.A.M Missionaries anci tho colonial government closely perionect their repective roles wore or luss hamoniously, though not as contortably as woulc have been axicted.

\section{I.B.L.A.: THE ECONOAIC FEOIO:}

The principal role or IBEA was one of conolic activity. This activity required a population with sone standard of healih. Where nucessary, huwever, the mininuril standard was set aside, presumably to increase the profit margin and also because health was not thought to have a direct contribution to jiofit naking. The litedical services of the I.B.E.A. Coupanj were therefore linited to the enployees of the Coipany but not tinuir relatives. Qumtity and the guality of the servicus offerea progressively declined rom the Europeans through the Asian to the Airicans. Jittlo atteript was nade to reach the rural oettlenerts where the Airican labour actually originatid. This becare evident during tho first world war. When Africans wer subjected to istical exulination to find out whether they. were eligible to join the wilitary activities, $34 \%$ of recruits 


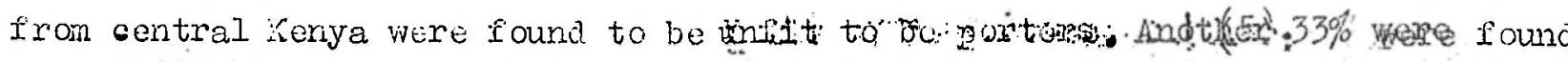
to be unfit ever as labourers! (5). For tine guncral population the prevailing Low socioeconoilc conditions, including housing, sanitation and other environmental deficiences in a wiaer cnvironnent of walaria, jlasue trypanosomaiasis, to narie but a few, contributea to the unexpectedly high jorbidity and mortality patterns.

Even though the soldiers, the porters and the labourers in the amy were the select healthy minority, they lived under haishly sub unen conditions from where they inherited other diseases, like syphilis, and conconitant weaknesses. This was evident during the war. It is said that of the 4,300 Kenyans killed in the rilitary $7 \%$ succuribed to disease. Ever the carriers who were Guppasad:to bo wa health standard were not irmune to disease. The newly acquired disease wero then takin back to the native reserves where they easily spread. Perhaps owing partly to the poor uncerstanding of epideniology at that time and partly to resource constraints, colonial authorities saw no need to take any precaution to protect the natives from disease to which they had no imrnunity. On the whole, then what is generally called "peacerul permeation of western civilization", was clearly a forceíul and brutal,-though not necessarily, deliberate,-penetration of Western socioeconouic pursuits into African the benefits fron western civilization ind econonic benefits were not as easily perneating into the Natives as the furces of donination.

A modern systen that juxinates the IBEA heolth service systens. is the occupational health servicus syster, that is of ten beyond the reach of those. outside the particular occupation or economic concurn. Sone organizations Ijke the arried forces, large plintations and nost of the incustrial concerns provide curative services for their workers and their faulies. As the manufacturing organizations are generally based in uiban centres, the occupation health system, together with other systeis, enhances the uronnization of health care, Inadvertently, the gap between the quantity and quality of urban care and rural care continues to incruse with econoiic devilopront.

\section{THE MISSIONAHY FACTOR}

The Misisionary factor in the developrient of health services in Kenya has never beeir doubted. But tho relationship between the religious groups and the colonial governmont is still a contraversial issue. It is necsssary, however, to look into the contributions of the religious groups and the rationale behind their work in order to undarstand the current situation $(6,7)$.

The relationship batween lajisionaries to Airica and European expansio-

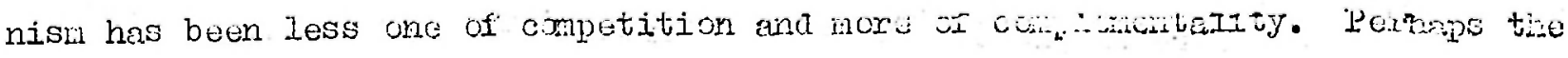


belief comon ariong African intellectuals that the Bible was the stanaard for the gun is not completely urifounded.

The missionary morkers are know to heve played their cards wil to again recognition and favour anong the Af ican rulurs. Medical knowledge and the art of readins and miting wro anone thoso cards. In the Buganda for instance Speke is gaid to have inpressed and befricndud til Kabaka (King) in 1860 only when he nade use of his madimentary nedical knovludge (7). In 1878, the first medical missicnary was asked to pruvide iacical advice to the Kabalia's palace. By way of ruciprocity the Kabaika bestowed hiis own blessing on the missionery and christian work. By and large such blessing lasted until the Kabaka's menory was adulterateci by a new curiosity about other missionaries. Father Lourdel, the first Catholic lissionary to Buganda successiully treated the Kabaka for dysentry lergely to attract the King's attuntion and the priviloges accruine fron the King's satisfaction. As a conscquence of aedical airacles, the missionaries were permitted to preach and christiolize in the Kingaon.

In Kenya too, healing wont hand in hand vitin proselytization. Perhaps promises of spiritual rewerus in the next life required jrecursors in the form of earthly rewards like health. Both the Catholic ind the Protestants recognised health work as a potenticily converting clement. The iaissionaries were quick to realize that the praise of the rew God and tilu attompt to banish the old were not sulficient to convince the ratives after all.

Although bissionaries opened up cutposts in rerote aroas and larger 'health centres' in their nore iraportant areas, thoir inpact in the reserves remained low in a few places and ail in rost commities. This fact cane to light during the First World Vlar as inuted esrlier when the health of ilost of the would-be military conscripts was found to be less than that which the colonial govemrent expected after nearly two decacies of aninistrative activities.

The second half of 1920 s saw the expansion of both adrinistrative and rissionery hedical work in reponso to the earlier diseppointment. By and large, hawever, the religious nedical services went, exclusively to the African and Asien comanitius. In spite of oubious aotives initially, missionary sedical activities were the single inost inportant attempt to affoct Africans, in their own environjent, outside the preveiling colonial structure, The missionarius may not have proviüd cuality care, but coertainly provided a signipicant portion or the services though not edequate in quantity na extent of coverage,

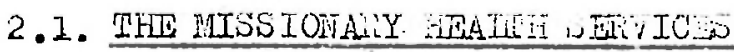

Today as in the yost the missionary healuin care systeri has folluned 
the denowinational pattern of acceptance and establishnent. For instance, neither the Catholics nor the Protestints church groups have set up a health facility where they do not have a strong following. The health care facility is more often then not a reward to the comunity for accepting the church and an incentive for the doubtrul to comit thenselves. Mhough theoretically a religious comunity need not express itself tirough the physical building of a church, in practice the cliurch building becones an inportant and often necessary symbol and bose. Tirroughout the inissionary presence in Airica the same pattern has dominated heslth ard education activities. Hospitals and schools are seen as the ultinate realisation of health care and education.

The missionary health care sjstem ha timu been largely a static-facility-based in rural areas. These iteilities are better equiped and staffed then comparable governnent service points. The focus of the system has been the provision of basic curative servicas recuired in the maral an of ten

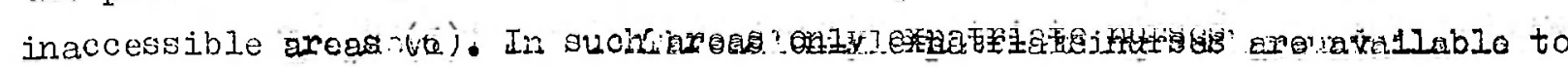
provide care. The cultural and training back grounds are not inconsequent to the type of services they emphasize. But the trend is currently changing in fevour of comnunity-based care. The resources the missionaries have, however, are often far too inadequate for rapid expanion of their activities where they are nost needed.

\section{THE GOVNATILENL/PUBLIC EAOTOR}

Within a bourins countries, had three distinct racial srouping, the European, the Asian and the African. The three groups were the basis for the three medical systems (5). As stated earlier the European group assunea the directorship of political power. The Asian froup distantly rollowed and even rore distantly, the African "tribes". or natives, a term used pejoratively. The Bucopean, the Asian and the Native hospital were not established by accicient, they were designed to emphasize the fundomental chasms aividing the three racial groups, and perhaps the colonial administrators becare no less a cherlatan in political manipulation than in the use of healtir developrent. As a rule it was decided that the health systen provided to the ifatives wa to be for the purpose of keeping thein usable-that is, exploitable - by the Exropeen intropreneurs and civil servants. Not suprisingly, colonial adrinistrative and econonic developnent, religious expansiow and health caro growth followed sivilar paths. Indeed they vere Ins arabion.

Just as there was a three-tiered systern of health are, each level .... 


\section{$-9-$ \\ IDO/WR374.}

serving its particular group. Theso wer Turopean hospitals, Africa hospitals and "Asiatic Mards". Later the Asian Conitunities vure able to establish their own Asian Hospitals notable we Ağ Khan in Nairobi ond the Tandja Clinic in Lombase. There used to be European doctors, hisian coctors but no African doctors. The colonial govermment position was tinet the African lackea a well devuloped broin : to learn any advanced work anü, in elly case, he could not perforra tasks indiupendently.

The training of African medical orderlice to itafî dispensaries began in 1920 but training of doctors for ligh, nore conplex tasks did not start until about 1935. Even then, iacilities were linited to a fur. The nodical raduatos froin Makerere, a constituent college of the University of Lonkion, were very slow in coning. For instance ui to 1949, only 15 griduates hes been producso for a period of 14 years. Even after troining, the African medical graduates had to serve under European and Asian doctors. A Furopena graunte was a "liedical of icer"l-an Asian sraduete was an "Auian liedical ofijecr" and the Natives were "Assistent Medical Officers". Tlepuris from the latter inaicate that the African doctors received discourafing encounters from other nedical colleagues, even in the wards. The vard sisters, invariable Europeens, could sonetines insult the African doetors with inpunity. Prescriyticns order by Airican doctors were subject to changes bj the sisters. In addition, the so-called Assistant Medicol officers were discourage fron warther mining in specialist areas. This largely. arplains why the current top medical specislists in Kinya hai to leave govemnent service in oraer to specialize.

Public nedical services were linitea to the urban centres and to those areas considered to have adeyuately accepter colonial rule. The relotionsiaip between the provision oi nedical services and the ouinistration is not quite incidental. In most ceses medical survices mere the reverds for subservience. In this regard the adninistration differed markedly fron the missionary: thic latter using medical scrvices to gain access to the native souls. For the governinent, however, wedicine and politics were seen as the legudery carrot wild stick. A pioneering colonial doctor-, for uxulple, once snic that it was necessury to Give "the Native tangible evidence that govemuent is souething more than a mere tax eollection" (8) in justifying his recomendetions for increased buläet for the health depertment. Even aftur the Africar heul divel fighting for the oolonial crown, the najor causes of deatin, plasue, nalaria, sleeping sickness, influenzo and environrintal sinitation hazerds rensined lerrgely untouched. The humanterion aspect of nulicine hed yet to resch the arrican ressves. In addition the introduction of the new medical tecirology wo not sccompanied by conconitant changes in the living styles. Consequentily, tire new technology wh used to treat illness as presented, without any aignificant attmipt to get the ceus as of the illness. No medical systen can be successful it it morls in thet kind of vacuura where the 
society, which gives rise to the health problers intended to be controlled, is ignored.

It should be noted, however, that the nedical departinent was not free in its own adninistration. The colonial office departinents and at times laid down regulations in respect to the stratesies for achieving the objectives. Budgetary inputs vere irposed by the colonial office: the departint could not alter the budget presented. This was strong levarage on the purt of the colonial office.

Racial differentiation was a necessary condition for colonial zule. As far back as 1903, the colonial oifice specified the opjectives of the nedical degartient as, firstiy, to preserve the health of the European coumunity, especially the government of icicials: secondly, to ensure thet the native and Asion labour force was in good working condition: and thirdly, to prevent the spread of infectious disease comn in the region. Accordingly, there was greater financial outlay for the Europeans and Asians than for the African groups.

Tror instance at the mental hospital, the retio of African to Europend Asian cost per patient bed-day was about $1: 5$ in 1945 and 1946 , and about 1:3 from 1947 to 1949 (3). At this hospital, the Arrican patients were kept "in the totally unsuitable prison onvironment" awaiting vacancies to be found, (enphasis acided) Por the other races, such conatitions were never allowed. An instance of the state of the European patient appears in the 1949 Annul Report where it is said:-

"Comportable and hoinely furnishings wero provided on a scale for more generous than ever before" (p.34)

\subsection{PUBIIC FERIIIE CARE SYSTEZ IODAY}

There exist four nain contenders for determining health goals: the individual, the professional providor of care, the Bovernment or policy maker, and the cominity. For each of these health goals are of ten expressed as demands for action to cure a previlin: or perceived health problem. Health foels way be identical for a number of groups, yet the strategies to achieve the goals are often dissimilar and sometines contradictory. At the very elementary level, the chosen strategies will be circunscribed by the previling sociopolitical systen, technology, socioecononic and cultural values and attitudes towards both the assumed problems and the assurned benefits.

How do you convince an individual patient "treat thyself" when the problom is seemingly self-inflicted? How con the individusl medical professional be convinced that "prevention is better then cure" when he earns his livelihood by treating the sick? Business ethics has it that no business pers on should try to 
run hinself out of business. Similarly a coriunity nay deund visible elenonts of health care, - a hospital - even though that maj not be what i.s needed.

The same problem affects policy makers: that is the dileinila between providing and supporting $L$ the glamorous institutions on the one hand, and the less politically visible although nore protical instituitions, on the other.

In Kenya ana other African countries ther are Elways the demands from the najority for frore and better heslth services. juch health services are not necessarily the nost technologically sophisticated. A small minority clanours ior sophisticated cexe. Unfortunately, tric uinority do not share in either the problems or the perceptions of the majority, nost of whois nay be poor, illiterate and politically isolated $(9)$.

For policy-makinis purpose the latter segrent of the Kenyan society, comprising over $70 \%$ of the population, is, iri reality, a nunerical majority. History has shown that tilis majority's choices may be linited by the choices of the minority, smalles in numerical terms, wut greater in political power. What the majority may want is subject to approvel by the elite. What the latter want is $:$ is what they will fight ior and $i$ what nay be instituted. If the numerical nejority, in this case the rural massus, do not want large houjpital, they will have it anyway. That is the current situation in Kenya. In spito of extrenely grandiose rural healtin develo pinent rhetoric, höpital developint and mointenance absorbs the lion's share of the health budget. In staff deviloprent post-rraduate training (specialisation) is beconing the nom in a country where the populationdoctor ratio is over 50,000:1; Paradoxically the wajor hacilth problens and causes of dcuth are largely duc to enviruniental health and socioecononic deficiencies. However, redical eduction, lasgely clinidal and institution-bosed, is tailored alonE the standards iriported fron Britain, ever though Kanya and Britain have little in colliion in tems of health problems. The soal in the reaical profession is to prualuce nedical doctors with an international flavour conplete with colleges or Physicians, surgeons etc. (anr Cominuity-based or prinary health care has no plece.)

Chargeteristically, t.e nenaghent of the needs and worries of the rany are controllea by the winurity of iritellectuals, wrofessionals, business leaders and, not least, policy malcers. In this, Kenya is not peculiar. As we have seen there are sociopolitical procedents.

Wure the national resources utilized nore retionally, the curronty available knowleage would rutuce whooping cough, Wij, wD, URTI GE and others by 
100\%. Nutrition disorders could be recuced by 70-80\% within rive years.

The rajor rias on for current health developinent trends is a paradox so gross as to be pathological anong health professionals, health nanagerial ranks and other elites. (10-12) on the one hand, is the increasing denand by the elite for tire establishment of what is assuned to be the "West" care aviilabie. on the other hand, is the nerlected realisation of tine increasing need for basic health care scrvicos in rural areas where at present the least quality care exists in nost parts of the country. The demands have becn especially achieved in urban areas and for the better paid ranks. But for the riajority neither the quality nor the quantity is of adequate level. There is a conspicuous lack of balance in the health plens and prograriming. Reluctant attempts on the part of the elite to reconcile these two denands has led to the existence of a menagerial malady which has paralysed effective heslth planining and service dolivery.

As in the.past, and presumably due to it, the Kenya health care structure has a distinct character that $\angle$ portrays botis the inaiviaualistic ideolowy established during colonial tines and a lack of perspective or? both priorities and viable direction. Indeed various health componnts tend to go their own way. e.g?

Althou the puidic health systen should provide health care to all equitably, the philosophical coals specified by the government health plans and international agencies have yet to be attained. The largest and best equipped hospitals are actually "Iolands of Froellence" in urban areas. The current systern has grom along the trend established by the colonial system.

Political activitius are penes played accoriano to curious rules for the nain actors vis-a-vis thoir followers. Social groups are mobilised around sorle arificulated objeotivea. Once elliances have been successully established, however, the rationable for political organization ofteil changes; there is no guarantee that the original objectivos inll be pursued*? In some cases, even when pursued new rules nay have to be iomilated. At indejendence the political Party, Kenya African National Union (KAIV) wa a strong i Iationalistic party. It collapsed. to near-extinction within a fow years. Politico-Aüinistrative power vis tiansferred froil the party and the parlianent to the Frovincial and District Comiasioners, exactl ${ }^{\prime}$, as it was during the colonial puriod!

African leaders have ierionstrated a tuev railures, arong which are their inability or urwillingness to rake strmetural changes in their independent republics. With a fow axceptions notably Tanzonia, Mozmibique and Guinea - the developrent philosophies in these rophlics are laroly borrowed fron Iomer colonising countries. Exoiples are numerous. In 1963, Kenya becane incependent 


$$
-13-\quad I D / F S 374
$$

of the Britisin colonial rule. One of the majorareas of contentions between the Europeans, on the one hand, and the Africans, on the other included inequitable distribution of resources and public bunefits. As we have seen, Buropecans controlled political debate, powcr, instmuents of political processes anà, inäead, the results. Large tracts of the best land were reierved for white famers. Most favourable urban residential areas, schoole end other anenities were set aside for whites. Debate nd araed clashes (hian wau wer) vere waged to mestle those priviloges fros Europeans and Asians or at least share thas equalitably with Africans ،

But into the shoes of the white man reacly steppec in the Black Kenyans endowed with education, leadership ibility and even wealth. Host of these had been the vanguard of the strugele for Uhuru (Inciepancience). Since uhuru, Kenya has been roughly dichotonised into a fer who inherited 'Mzungu's' (white nan's) privileges and consuraption habits and those who are still outslie the fomer privileges of the white ren - the nas.es. For the few, consipicucus consurption habits, crclusive residertal areas, schools and hospitals abound larely at the disposal of a near-exclusive clasi composed of expatriates, Asians and a corps of Africen elite, what Ireantz Fanon calls "Blacle Slsins, Fhite assks". The new society has distinct class character perines replacing the pre-uiuru racial criterion for access into privileges. It is not strange then thet the colonial institutional structuses exist, alnost intact. And the health systen is one such subsyster.

Indeed there are structural problwascononic and ideaological - entrenehing the systein. With the unendine cxponsion of how itals, the nore necory rural populations progressively becoles distranchised vis-in-vis urban populations in terns of the reletive sionificonce of mal health wenditures (13-15).

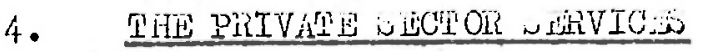

The developrent outlined above has indeucl curricd even equally into the private sector. This sector consisto of two levels.

a) Large scale and comper metropoliten hopital services operated on mules of the wrinet place. The guheris of thes hospitals is related to the historical racial segregation systen propated by the colonial foptmment. Accoräinsty the hojitals had been set up to surve the furopecn, the drian or other coriunit1es (17).

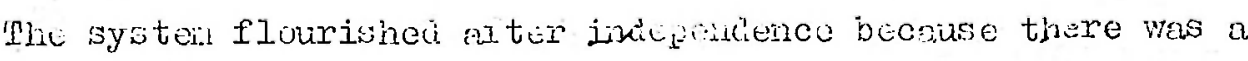

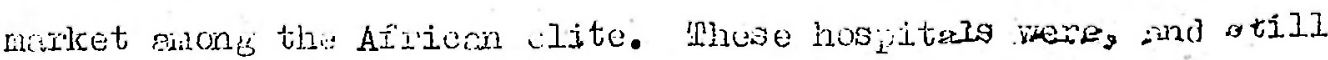
ere, to be tiound in thi...iejor citien. 
b) The seconu level consists of a host of private clinics of veryinesizes and copability, usually hola by one or hore doetors, ilost wi whon are cenersil prectitioners. The thrust of the rrocice is curative liedicine, nostly in urban settings where the worket is liree. Indece ielatively few people coin afford the services of private ductors, especially the specialized ondre.

As under the eccnonic and socio-political structure of colonial tiwes the privete sector tencis to operate on a business pattern. Cheracteristically specialization is a srowine tendency, and is considerea to be a necessary ochievanent in sume hospitels. The loctors'specialization requires specialized disgnostie and curative equipuent. Consequently the rioluine of exceptions I centres of excullence is alrealy of rality and the noril. surrisingly, the foverment health lan-power developinent systeil, ir which siecinists we producte at the expense of the public, inadvertently serves the on 0 the private sector. The quost for equitable aistribution or the cusantity and quality of care cannot bo net in this rinnor.

5. CONCLUS IONSS

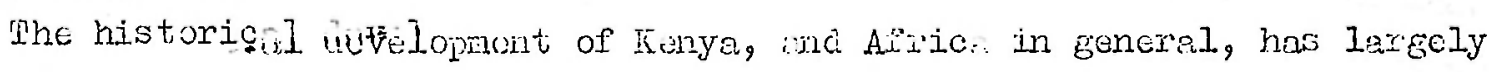
deteringed the existing health systes. Attenpts hove been inde to irovide health oproto the puople, who still have rencined largely in the periphery of health care prioritization. However, no drastic yolioy neosures have beci takin. toward structurel change of the heaith car sustem. Uncerstendably structura changes in large organizations ind burcaucracius are difficult and rare. In addition, structural changes aro econcitically expensiv. Nore otten then not bureacracies do their best to avota having to nalie structurn changes. But in a pour developine courtry, sucin chonges we necessary if sociol justice is to be equitably distributed.

The najor himdrences to the fomulation of woro effective heelth systens would appear to be tine value systeis of the elite roupa and aguncies, enci the structures these produce. Atteipts to $s$ live priority problems ang the larest proportion of the yoplation. leave wuch to be desired. Fristin: health struc-

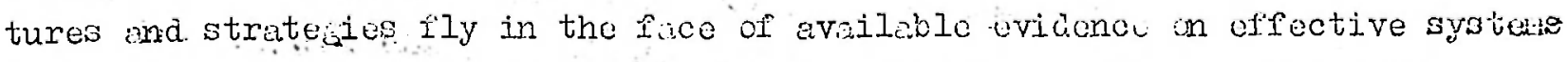
and statesis. In the conflict beween jolitical nocussity and oconoric reelity many probleras heve been avoided ratiner than solved. These problens do not disappear, they grow and naginy. It is the poblews we heve ignored, rather than 
those we have iailed to concuer, thet are constant dificulties. The challenge in modern inealtir care practice is to lesion systen the are not only fair and just to all but effeciont and efrective. It is ise as sull challenge.

If Kenyons of Africen wtraction round the colonial health systen unjust, they nust also strive to oroste a systen that is 1 ot dispropurtionately

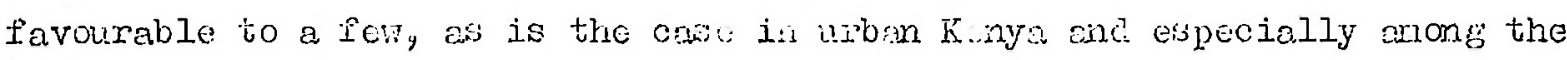
"irofessionals" . Thu African Black elites, iomerly "native elites" heve inherited the forwerly aclusive Europen ane "Asietic" tastes, hospitals and private clinics and, inevitably, class distinctions. The professionalization currently pursued liay not be in the bost intersit vi the nejority tor every few will ever afford the high "profussionol fees". As George Bernerd bhow once said:- "Bvery profession is a conspiracy aguinst the public". Mocifyins that statement scilewhat, Reno Dubos (18), said that inciviulualized health care, cowion aniong ayecialists, untrenches the status quo, which reans thet the control of those conditions which lead to individual comunity-bide problens is progressively less important except in rhetoric. political action is nccessary to wake rolevant and

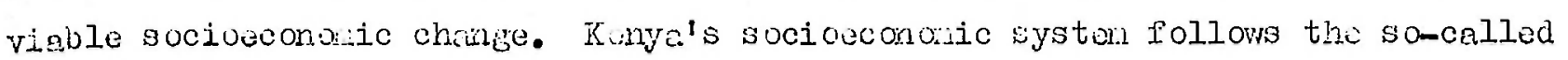
free-enterprise fihilos ophy lons established during the colonial days but now aùvanced to a very high docree. Within tinis avelopuent ideology denocracy and social justice are dipectea to thrive. One coivon incer of these goals whould be the distribution of wocial survices aions the Kinyon's. The pertorance of Kenya's politico-adinistrative institutions shoula thus be assessed in that context.

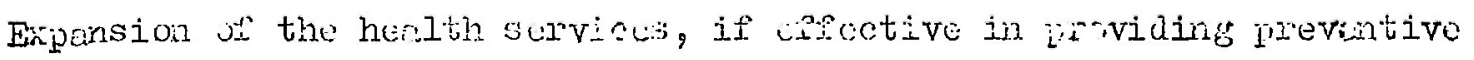
and basic curative care, will be a cuntribution toward socioeconoilc deiocratization. In a iundental manner democrscy mat also include equitable cocessibility to basic necals of life, and health is one of thw. The question in this paper is directed tomards how fan the existing systen anc its institutions an produce the expansion of health services necessary io bring health to the whole population. 